\title{
Reproductive effects of the anti-cancer drug procarbazine in male rats at different ages
}

\author{
J. F. Velez de la Calle, J. Cl. Soufirt, F. Chodorget, Cl. Boisseau, \\ H. Kercret* and B. Jégou
}

Laboratoires de Biologie de la Reproduction et de *Biochimie Générale, UA CNRS 256, Campus de Beaulieu, 35042 Rennes Cédex, France; and †iologie Cellulaire, Faculté de Médecine,

94270 Kremlin Bicètre, France

\begin{abstract}
Summary. Rats aged 10 days (Exp. A), 45 days (Exp. B) and 70-90 days (Exp. C) were given procarbazine intraperitoneally at doses of $30 \mathrm{mg} / \mathrm{kg}$ /day for 5 or 9 weeks (Exps $\mathrm{A}, \mathrm{B}, \mathrm{C}$ ), or by gavage at doses of $5 \mathrm{mg} / \mathrm{kg} /$ day (equivalent to the therapeutic dose in man) and $50 \mathrm{mg} / \mathrm{kg} /$ day, for 9 weeks (Exp. B). A significant mortality rate was noted in immature rats (Exp. A) and in animals receiving $50 \mathrm{mg} / \mathrm{kg} /$ day orally (Exp. B). In all groups the rate of body weight gain and the weights of the testes and epididymides were reduced. Procarbazine produced disruption of the normal spermatogenetic architecture that was very severe or total in immature rats (Exp. A) and in rats given the drug at $30 \mathrm{mg} / \mathrm{kg} / \mathrm{day}$ for 9 weeks and the highest dose $(50 \mathrm{mg} / \mathrm{kg})$ in Exp. B. Disruption of spermatogenesis was only partial in the other experimental groups. The number of Sertoli cells was not affected by the different treatments, but a Sertoli cell dysfunction (vacuolization, decreased ABP and elevated FSH concentrations), most probably secondary to germ cell degeneration, was demonstrated in those rats presenting the most severe disruption of spermatogenesis (Exp. B: i.p. and gavage, $50 \mathrm{mg} / \mathrm{kg}$ for 9 weeks). Leydig cells, always present in the interstitium, were moderately affected (decrease in serum testosterone values) in some groups at all ages whereas epididymal sperm reserves were decreased after 9 weeks (Exp. B: $30 \mathrm{mg} / \mathrm{kg}$, i.p.; 5 and $50 \mathrm{mg} / \mathrm{kg}$, gavage). Moreover, there was a marked fall in the number of fetuses per female mated by males in all experimental groups. We conclude that the effects of procarbazine on male reproductive function were independent of the route of administration, greater before puberty and proportional to the dose administered as well as to the duration of the treatment.
\end{abstract}

Keywords: anti-cancer drugs; procarbazine; rat; testis; epididymis; Sertoli cells; Leydig cells; spermatozoa; fertility

\section{Introduction}

Polychemotherapies used in the treatment of cancers such as Hodgkin's disease, testicular cancer and medulloblastoma have been known for many years to induce a very high rate of sterility in men (see reviews by Schilsky et al., 1980; DeVita, 1981; Shalet, 1983). Among the agents frequently used in these combination chemotherapies, procarbazine a methylhydrazine derivative, has been shown to be capable of inducing severe damage to the seminiferous epithelium in rodents (Hilsher \& Reichelt, 1968; Lee \& Dixon, 1972; Parvinen, 1979; Meistrich et al., 1982; Sotomayor et al., 1982; Abraham \& Frantz, 1983; Gould et al., 1983; Russell et al., 1983a, b) and in monkeys (Sieber et al., 1978). However, whether or not this compound acts on testicular cells other than germ cells is not clearly established. The purpose of the following experiments was to evaluate the changes in 
spermatogenesis, Sertoli cell and Leydig cell functions, sperm reserves and fertility when procarbazine is administered to rats at different ages and by different routes.

\section{Materials and Methods}

Procarbazine (Natulan ${ }^{\circledR}$ ) was kindly provided by Roche Laboratories (Neuilly sur Seine, France) and was diluted with a phosphate-buffered saline solution (PBS: $136 \mathrm{~mm}-\mathrm{NaCl} ; 6.7 \mathrm{~mm}-\mathrm{Na}_{2} \mathrm{HPO}_{4} .12 \mathrm{H}_{2} \mathrm{O} ; 2.6 \mathrm{~mm}-\mathrm{KCl}$; and $1.4 \mathrm{~mm}-$ $\mathrm{KH}_{2} \mathrm{PO}_{4} ; \mathrm{pH} 7.4$ ). Male and female Sprague-Dawley rats were maintained on standard rat chow and allowed food and water ad libitum.

Treatment protocol. Several experiments were performed on male rats of different ages (4-7 per group). In Exp. A, 10-day-old rats (immature) were injected daily, intraperitoneally (i.p.) with $30 \mathrm{mg}$ procarbazine $/ \mathrm{kg}$ for 5 weeks. In Exp. B, 45-day-old rats were given procarbazine at a dose of $30 \mathrm{mg} / \mathrm{kg} /$ day, i.p. for 5 or 9 weeks, or $5 \mathrm{mg} / \mathrm{kg} /$ day (dose chosen based on recommended dose in man) or $50 \mathrm{mg} / \mathrm{kg} / \mathrm{day}$, by gavage and for 9 weeks. In Exp. C, 70-90-day-old rats were injected i.p. with $30 \mathrm{mg}$ procarbazine $/ \mathrm{kg} /$ day for 5 weeks. Depending on the treatment, animals were weighed daily or weekly and the doses of procarbazine were adjusted accordingly. Control males were given equal volumes of PBS. The volume of PBS injected ranged from $0.2 \mathrm{ml}$ to a maximum of $0.5 \mathrm{ml}$.

Collection and preparation of tissues. After the treatment periods the animals were killed by decapitation and blood was collected and allowed to clot. The serum was stored at $-20^{\circ} \mathrm{C}$ for hormone assay. The testes and epididymides were dissected out, weighed and prepared for histological observation and assessment of testicular characteristics.

Histology. Testes of rats in each experimental group were fixed by immersion in Bouin-Holland solution and embedded in paraffin wax. The tissues were processed for light microscopy and sections $(3 \mu \mathrm{m})$ were stained with periodic acid-Schiff. No quantitative studies were performed, but several entire cross-sections of the testes from each rat were assessed by two different trained examiners.

In-vitro production of testosterone. After decapsulation, hemi-testes from the experimental animals (4-5 per group) were incubated for $4 \mathrm{~h}$ at $34^{\circ} \mathrm{C}$ in a shaking water bath in $2 \mathrm{ml}$ phosphate-buffered saline solution (PBS, pH 7.4; see composition above) with the addition of glucose $(1 \mathrm{mg} / \mathrm{ml})$, as previously described (de Kretser et al., 1979; Jégou et al. 1984); one-half of each testis was used to indicate basal production of testosterone and the other half was stimulated by including hCG (700 mi.u./ml; Pregnyl: Organon; Eragny sur Epte-France) in the PBS. At the end of the incubation period the media were centrifuged at $2000 \mathrm{~g}$ for $15 \mathrm{~min}$, and the supernatants stored at $-20^{\circ} \mathrm{C}$ until assayed for testosterone.

Measurement of androgen-binding protein $(A B P)$. The heads of the epididymides were homogenized and centrifuged at $105000 \mathrm{~g}$ to provide a cytosol preparation for measurement of ABP by steady-state polyacrylamide gel electrophoresis (Ritzén et al., 1974). The results are expressed as the ABP content per organ.

Hormonal measurements. Concentrations of testosterone in serum were measured after extraction with a mixture of cyclohexane-ethyl acetate $(1: 1, \mathrm{v} / \mathrm{v})$ using a radioimmunoassay previously described by Garnier et al. (1978). The antiserum was raised in a rabbit against testosterone-3-O-carboxymethyloxime-bovine serum albumin (final dilution 1/15000) prepared by Dr M. Terqui and Dr D. H. Garnier at CRVZ, INRA (Nouzilly). This antiserum cross-reacts with dihydrotestosterone ( $60 \%$ with $5 \alpha$-DHT and $20 \%$ with $5 \beta$-DHT) and $5 \alpha$-androstanediol $(36 \%$ with $3 \alpha, 17 \beta$ - and $25 \%$ with $3 \beta, 17 \beta-$-). The intra-assay coefficient of variation ranged from 10 to $13 \%$ according to the levels assayed. All samples were measured in one assay.

Concentrations in the incubation media were assayed without extraction as described by Garnier et al. (1978). This had no effect on the results (data not shown). The intra-assay coefficient of variation was $7 \%$ and all samples were measured in one assay. The minimum detectable testosterone concentrations were $50-100 \mathrm{pg} / \mathrm{ml}$

Serum LH and FSH were assayed using specific double-antibody radioimmunoassays with reagents kindly supplied by the National Pituitary Agency. Purified rat LH (NIAMDD-rLH-I6) was used as a standard and tracer for the LH assay. Purified rat FSH (NIAMDD-rFSH-RP) was used as tracer for the FSH assay. The minimum detectable plasma LH and FSH concentrations were $0 \cdot 1 \mathrm{ng} / \mathrm{ml}$ and $l \mathrm{ng} / \mathrm{ml}$ respectively. The intra-assay coefficient of variation for both assays ranged from 5 to $7 \%$ and all samples from the experiment were measured in the same assay.

Sperm reserves and fertility testing. The numbers of spermatozoa present in homogenates of the caput epididymidis were determined by the technique of Robb et al. (1978). At 1 week before the end of treatment, fertility testing was performed on 5 control and 5 treated rats taken at random in these respective groups: each male was housed with 2 mature, cycling females for 1 week. After 19 days the females were killed and the number of fetuses per female counted. No measurements of sperm reserves or mating trials were performed in Exp. A because the rats were too young.

Statistical analysis. Results were expressed as means \pm s.e.m. Analyses of variance, Student's $t$ test or the Wilcoxon test were used for comparing differences between different groups. A probability of $<0.05$ was assumed to denote a significant difference. 


\section{Results}

Body weight

Rats of all experimental groups showed a significant decrease in body weight gain after administration of procarbazine for 1-2 weeks except those receiving $30 \mathrm{mg} / \mathrm{kg}$ in Exp. C (Fig. 1). The most dramatic decreases were observed in immature rats (Exp. A) and in animals treated with the higher doses in Exp. B. A high rate of mortality was observed in Exp. A ( $25 \%$ after 4 weeks) and in rats receiving $50 \mathrm{mg} / \mathrm{kg} /$ day orally $(75 \%$; Exp. B). No mortality was observed in the other experimental groups.

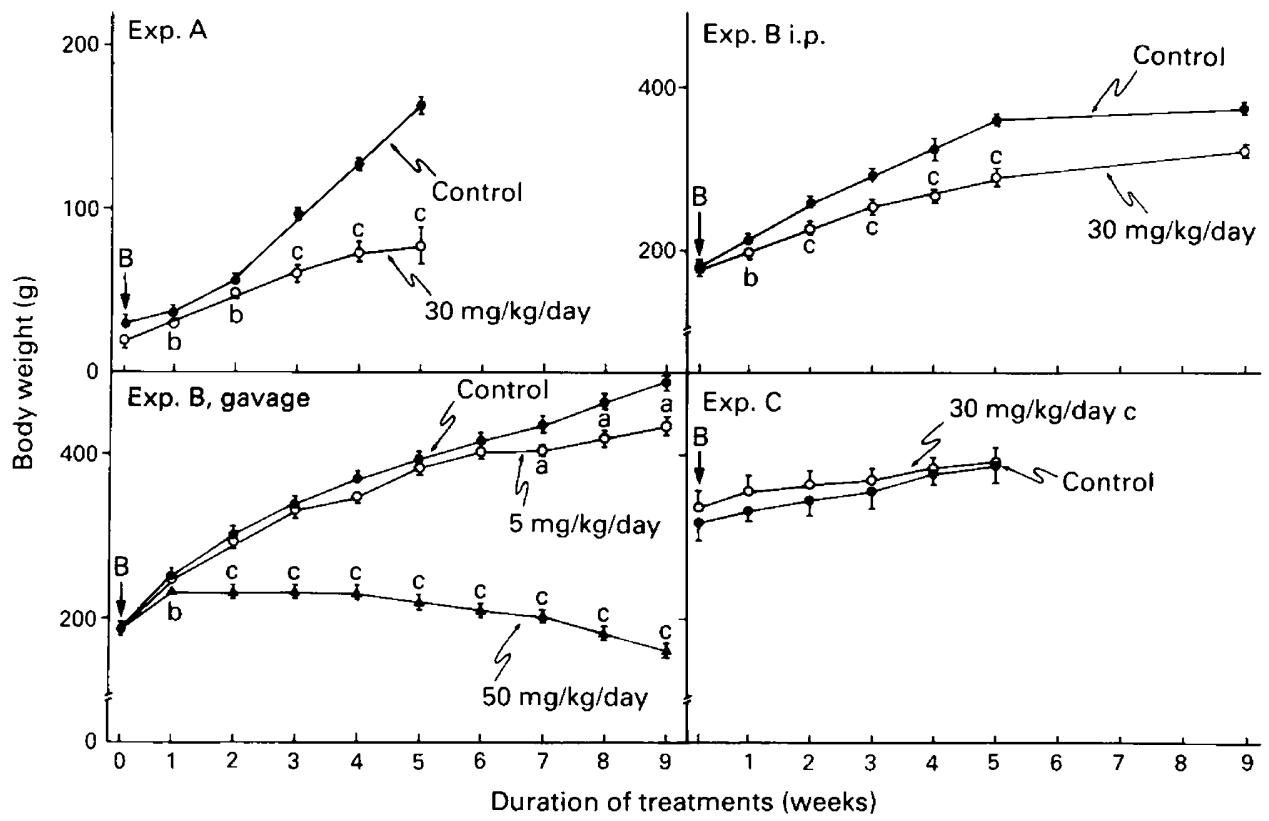

Fig. 1. Effect of procarbazine in body weight gain of rats of different ages. Ages of the rats at the start (arrow) of the treatment periods (see text). Values are mean \pm s.e.m. for 4-7 animals. a, $P<0.05 ; \mathrm{b}, P<0.01$; c, $P<0.001$, when compared to control values.

\section{Reproductive organ weights}

Administration of procarbazine induced a significant decrease in testicular and epididymal weights in all the experimental groups except in Exp. C in which no significant change was seen (Table 1). However, when values were expressed as relative reproductive organ weight (organ weight $/ 100 \mathrm{~g}$ body weight), testicular weight was still significantly decreased in all groups whereas the relative epididymal weight was only significantly decreased in the rats of Exp. B receiving $50 \mathrm{mg}$ procarbazine (data not shown).

\section{Histological study}

Histological characteristics of a normal 45-day-old rat testis (age of rats at the end of treatment in Exp. A) are represented (Fig. 2a). After treatment of immature rats with procarbazine (Exp. A), the seminiferous tubules were greatly reduced in diameter. These tubules were lined by Sertoli cells 
Table 1. Effect of procarbazine on reproductive organ weight and on hormone concentrations in rats

\begin{tabular}{|c|c|c|c|c|c|c|}
\hline Experimental gro & & $\begin{array}{l}\text { Testis wt } \\
\text { (g) }\end{array}$ & $\begin{array}{l}\text { Epididymal wt } \\
\text { (g) }\end{array}$ & $\begin{array}{l}\text { Testosterone } \\
\text { (ng/ml) }\end{array}$ & $\underset{(\mathrm{ng} / \mathrm{ml})}{\mathrm{LH}}$ & $\begin{array}{l}\text { FSH } \\
(\mathrm{ng} / \mathrm{ml})\end{array}$ \\
\hline $\begin{array}{l}\text { Experiment } A \\
\quad 30 \mathrm{mg} / \mathrm{kg} / \mathrm{day} \\
\quad \text { for } 5 \text { weeks, } \\
\text { i.p. }\end{array}$ & $\begin{array}{l}\text { Control } \\
\text { Treated }\end{array}$ & $\begin{array}{c}0.81 \pm 0.05 \\
(5) \\
0 \cdot 13 \pm 0.01^{* *} \\
(5)\end{array}$ & $\begin{array}{c}0.12 \pm 0.02 \\
(5) \\
0.04 \pm 0 \cdot 01^{* *} \\
(5)\end{array}$ & $\begin{array}{c}0.7 \pm 0.2 \\
\\
(5) \\
0.2 \pm 0.1^{*} \\
\\
\end{array}$ & $\begin{array}{l}-\dagger \\
-\dagger\end{array}$ & $\begin{array}{l}-\dagger \\
-\dagger\end{array}$ \\
\hline $\begin{array}{l}\text { Experiment } B \\
30 \mathrm{mg} / \mathrm{kg} / \mathrm{day} \\
\text { for } 5 \text { weeks, } \\
\text { i.p. }\end{array}$ & $\begin{array}{l}\text { Control } \\
\text { Treated }\end{array}$ & $\begin{array}{c}1.81 \pm 0.05 \\
(6) \\
1.26 \pm 0.08^{* * *} \\
(6)\end{array}$ & $\begin{array}{c}0.46 \pm 0.02 \\
(6) \\
0.39 \pm 0.0 I^{* *} \\
(6)\end{array}$ & $\begin{array}{c}6 \cdot 6 \pm 1 \cdot 4 \\
\\
7 \cdot 1 \quad \pm 1 \cdot 2 \\
\\
\quad(6)\end{array}$ & $\begin{array}{c}0.25 \pm 0.02 \\
(6) \\
0.27 \pm 0.04 \\
\frac{(6)}{ \pm}\end{array}$ & $\begin{array}{c}20 \cdot 6 \pm 3 \cdot 5 \\
26 \cdot 9 \pm \frac{ \pm}{(6)} 3 \cdot 1\end{array}$ \\
\hline $\begin{array}{l}30 \mathrm{mg} / \mathrm{kg} / \mathrm{day} \\
\text { for } 9 \text { weeks, } \\
\text { i.p. }\end{array}$ & $\begin{array}{l}\text { Control } \\
\text { Treated }\end{array}$ & $\begin{array}{c}1.78 \pm 0.03 \\
(6) \\
0.91 \pm 0.07^{* * *} \\
(6)\end{array}$ & $\begin{array}{c}0.5 \pm 0.02 \\
(6) \\
0.33 \pm 0.01^{* * *} \\
(6)\end{array}$ & $\begin{array}{cc}6 \cdot 4 \pm 1 \cdot 3 \\
\\
(6) \\
3 \cdot 1 \pm 0 \cdot 6^{*} \\
\\
\\
(6)\end{array}$ & $\begin{array}{c}0.11 \pm 0.05 \\
(6) \\
0.28 \pm 0.01 \\
\frac{(6)}{ \pm}\end{array}$ & $\begin{array}{c}18 \cdot 8 \pm \frac{ \pm}{(6)} 1 \cdot 4 \\
24 \cdot 6 \frac{ \pm}{(6)} 2 \cdot 0^{*}\end{array}$ \\
\hline $\begin{array}{l}5 \mathrm{mg} / \mathrm{kg} / \mathrm{day} \\
\text { for } 9 \text { weeks, } \\
\text { gavage }\end{array}$ & $\begin{array}{l}\text { Control } \\
\text { Treated }\end{array}$ & $\begin{array}{c}2.14 \pm 0.05 \\
(5) \\
1.91 \pm 0.04^{*} \\
(5)\end{array}$ & $\begin{array}{c}0.69 \pm 0.01 \\
(5) \\
0.62 \pm 0.01 * * \\
(5)\end{array}$ & $\begin{array}{c}4.2 \pm 1.8 \\
(5) \\
2.5 \pm 0.6 \\
\\
(5)\end{array}$ & $\begin{array}{c}0.14 \pm 0.04 \\
\frac{(5)}{0.15 \pm 0.05} \\
\frac{(5)}{ \pm}\end{array}$ & $\begin{array}{c}30 \cdot 4 \pm \frac{ \pm}{(5)} 2 \cdot 9 \\
34 \cdot 5 \frac{ \pm}{(5)} 5 \cdot 6\end{array}$ \\
\hline $\begin{array}{c}50 \mathrm{mg} / \mathrm{kg} / \mathrm{day} \\
\text { for } 9 \text { weeks, } \\
\text { gavage }\end{array}$ & Treated & $\begin{array}{c}0.42 \pm 0.01^{* * *} \\
(2)\end{array}$ & $\begin{array}{c}0.2 \pm 0.04^{* * *} \\
(2)\end{array}$ & $0.25 \pm 0.01^{* * *}$ & $0.06 \pm 0.09$ & $30 \cdot 8 \pm \frac{1}{(2)}$ \\
\hline $\begin{array}{l}\text { Experiment } C \\
30 \mathrm{mg} / \mathrm{kg} / \text { day } \\
\text { for } 5 \text { weeks, } \\
\text { i.p. }\end{array}$ & $\begin{array}{l}\text { Control } \\
\text { Treated }\end{array}$ & $\begin{array}{c}1.71 \pm 0.04 \\
(6) \\
1.61 \pm 0.08 \\
(6)\end{array}$ & $\begin{array}{c}0.56 \pm 0.02 \\
(6) \\
0.54 \pm 0.02 \\
(6)\end{array}$ & $\begin{array}{c}6.7 \pm 0.87 \\
(5) \\
3.8 \pm 1 \cdot 1 \\
\quad(5)\end{array}$ & $\begin{array}{c}0.28 \pm 0 \cdot 04 \\
(5) \\
0.22 \pm 0.05 \\
\frac{(5)}{}\end{array}$ & $\begin{array}{l}27 \cdot 3 \pm 2 \cdot 9 \\
25 \cdot 9 \frac{ \pm}{(5)} 1 \cdot 6\end{array}$ \\
\hline
\end{tabular}

$\dagger$ The amounts of serum collected were too small to allow the assay of the hormones.

Values are means \pm s.e.m. for the number of rats in parentheses.

${ }^{*} P<0.05 ;{ }^{* *} P<0.01 ;{ }^{* * *} P<0.001$, compared with control value.

and the numbers of spermatogonia and primary spermatocytes were dramatically reduced. Leydig cells were present in the intertubular areas (Fig. 2b). The histological appearance of a normal adult rat testis is represented in Fig. 3(a). Injection of $30 \mathrm{mg}$ procarbazine/ $\mathrm{kg} /$ day for 5 weeks (Exps B and $\mathrm{C}$ ) induced a disruption of spermatogenesis in a few seminiferous tubules characterized by a decrease in the numbers of spermatogonia, primary spermatocytes and round and elongated spermatids. Other seminiferous tubules and interstitial areas appeared normal (not shown). With the prolongation of the treatment to 9 weeks in Exp. B, the number of damaged tubules increased markedly. The most damaged tubules contained only vacuolated Sertoli cells and very few germ cells (Fig. 3b). In Exp. B, at the lower dosage ( $5 \mathrm{mg} / \mathrm{kg} /$ day), treatment by gavage had no effect on the gross appearance of the testicular tissues (not shown) whereas the administration of $50 \mathrm{mg}$ procarbazine $/ \mathrm{kg} /$ day produced a majority of Sertoli cell-only tubules (Fig. 3c).

\section{Sertoli cell function}

$A B P$. The epididymal ABP contents of immature rats (Exp. A) and of the animals treated i.p. with $30 \mathrm{mg}$ procarbazine/ $\mathrm{kg} /$ day for 9 weeks (Exp. B) were significantly decreased whereas ABP was undetectable in rats treated for 9 weeks by gavage at the higher dosage (Exp. B; Fig. 4). The ABP contents were unchanged in the other experimental groups (Fig. 4). 

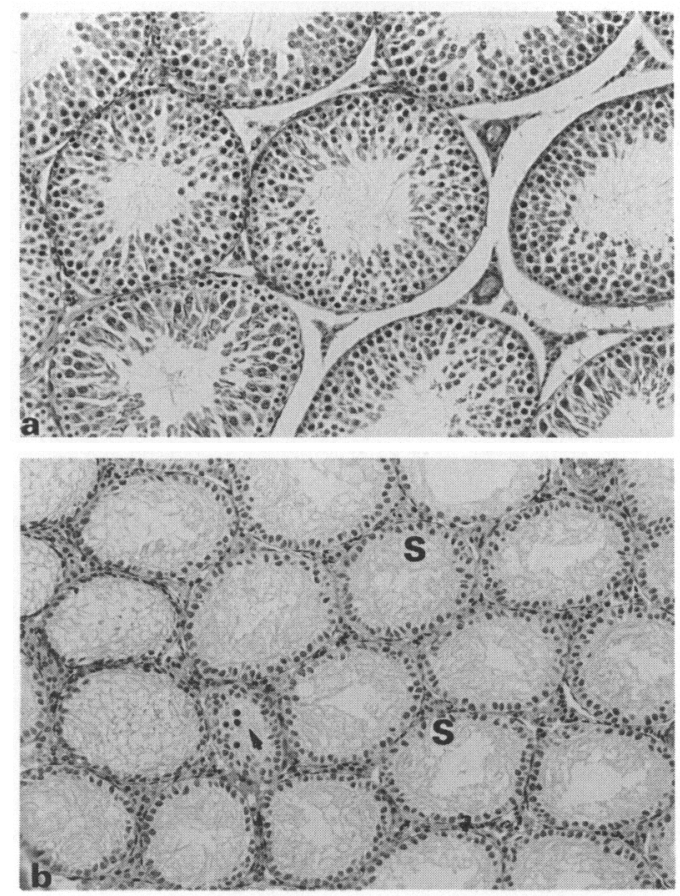

Fig. 2. Photomicrographs of testes from 45-day-old rats. (a) Normal rat showing that the most advanced cell types are elongated spermatids. $\times 90$. (b) Rat treated with procarbazine (i.p.) for 5 weeks, showing total disappearance of germ cells except in occasional seminiferous tubules in which a few germ cells remain (arrow). Sertoli cells lining the tubules are vacuolated (S). Also note the presence of intertubular tissue. $\times 90$.

Serum FSH concentrations. In rats receiving procarbazine at $30 \mathrm{mg} / \mathrm{kg} /$ day for 9 weeks (Exp. B) significant increases in FSH concentrations were observed. No significant change was seen in the other groups (Table 1).

\section{Leydig cell function}

Serum testosterone concentrations. No significant change was found in serum testosterone values in the animals treated for 5 weeks (Exps B and C), and in those treated by gavage with $5 \mathrm{mg} / \mathrm{kg}$, in comparison to their respective controls (Table 1). However, serum testosterone concentrations were significantly decreased in the immature rats (Exp. A), in the animals treated i.p. for 9 weeks and in those treated by gavage with $50 \mathrm{mg} / \mathrm{kg}$ (Exp. B).

Serum $L H$ concentrations. No significant differences were seen in any of the experimental groups (Table 1).

In-vitro testosterone production. No significant difference was found in basal and stimulated testosterone productions in vitro in any of the groups in which these values were assessed except in Exp. C in which a significant $(P<0.05)$ decrease in hCG-stimulated production was observed (Fig. 5).

\section{Number of epididymal spermatozoa and fertility testing}

There was no change in the number of epididymal spermatozoa in the rats treated for 5 weeks (Exps B and C) but this value was significantly reduced in the animals treated for 9 weeks i.p. or by gavage (Exp. B; Fig. 6).

Fertility testing demonstrated that the number of fertile males was comparable in the treated and in the control groups except in Exp. B in which all the males treated by gavage with a dose 

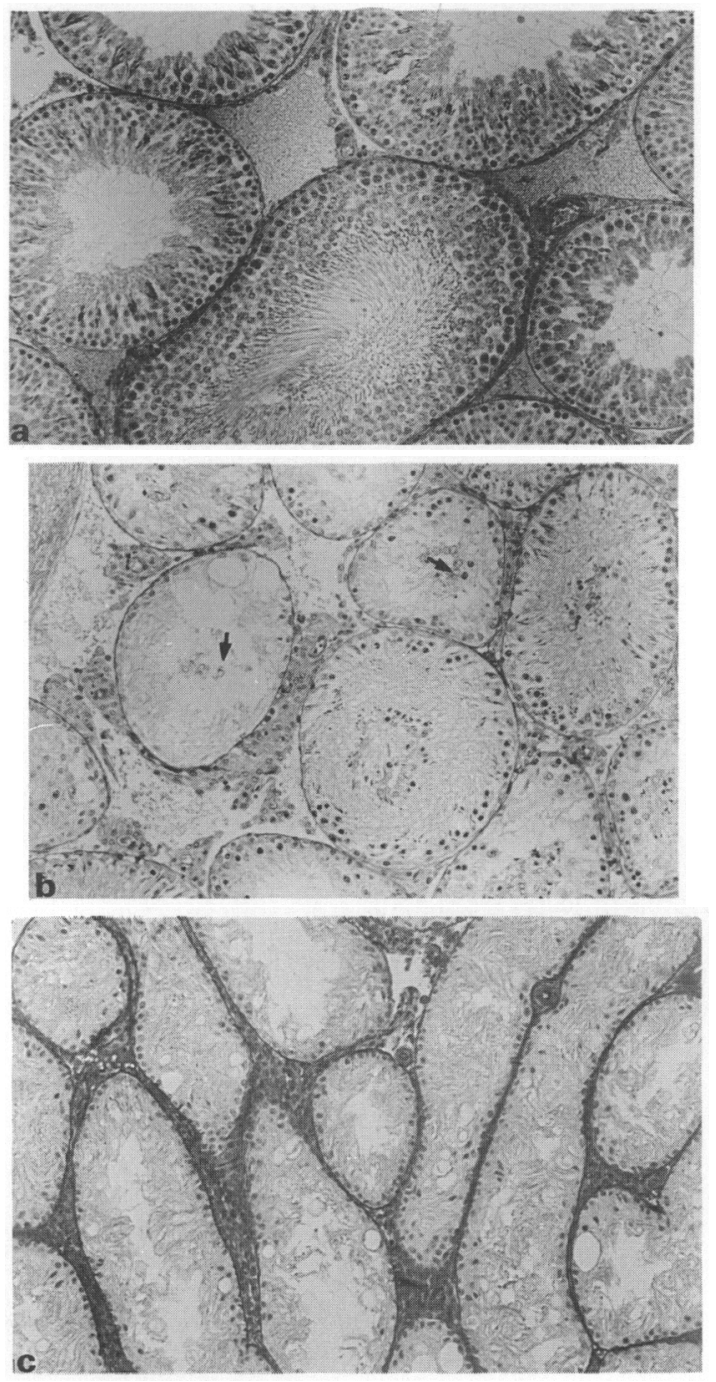

Fig. 3. Photomicrographs of testes from adult rats. $\times 90$. (a) Normal rat. (b) Rat treated (i.p.) with $30 \mathrm{mg}$ procarbazine $/ \mathrm{kg} /$ day for 9 weeks (Exp. B). The most damaged tubules are lined by vacuolated Sertoli cells contained very few germ cells (arrow). (c) Rat treated by gavage with $50 \mathrm{mg} / \mathrm{kg} /$ day for 9 weeks (Exp. B). Vacuolated Sertoli cells are almost the only cells present. Note the presence of interstitial tissue.

of $50 \mathrm{mg} / \mathrm{kg} /$ day were sterile (Table 2). In the rats treated with $30 \mathrm{mg} / \mathrm{kg} /$ day for 9 weeks (Exp. B) and for 5 weeks (Exp. C) a sharp decrease in the percentage of pregnant females occurred. There was also a marked fall in the number of fetuses per female in the groups receiving $30 \mathrm{mg}$ procarbazine $/ \mathrm{kg} /$ day (Exps B and C).

\section{Discussion}

In this study the tolerance of rats for procarbazine was good except in groups in which immature animals (Exp. A) or very high doses (Exp. B, $50 \mathrm{mg} / \mathrm{kg}$ ) were used. In these groups the mortality 
FExp.At $\vdash$ Exp.B $\mathrm{B}$ - $E x p . C-$

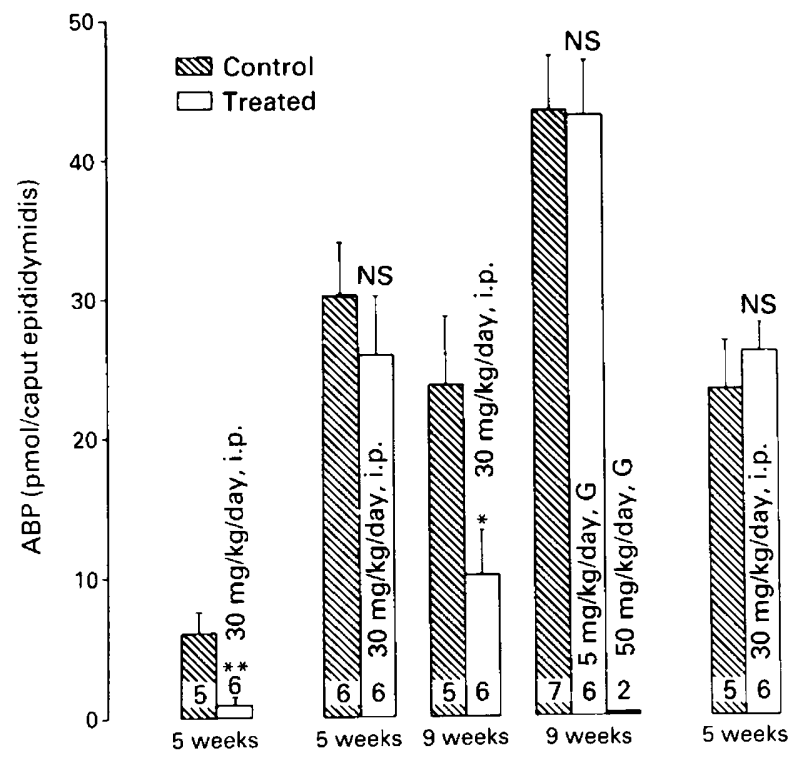

Fig. 4. Effect of procarbazine on the ABP content of the heads of the epididymides. Values are mean \pm s.e.m. for the number of rats indicated per group. ${ }^{*} P<0.05 ;{ }^{* *} P<0.001$; NS, not significant; i.p. = intraperitoneal; $\mathrm{G}=$ gavage.

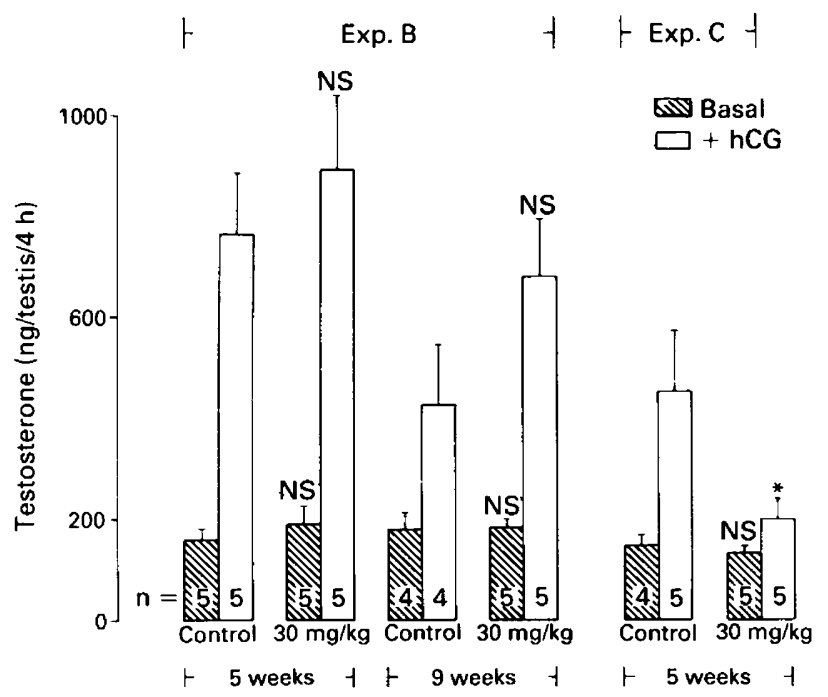

Fig. 5. Effect of procarbazine on in-vitro testosterone production over $4 \mathrm{~h}$ (see 'Methods'). Values are mean \pm s.e.m. for the number of testes incubated. ${ }^{*} P<0.05$, compared with control. NS $=$ not significant. 


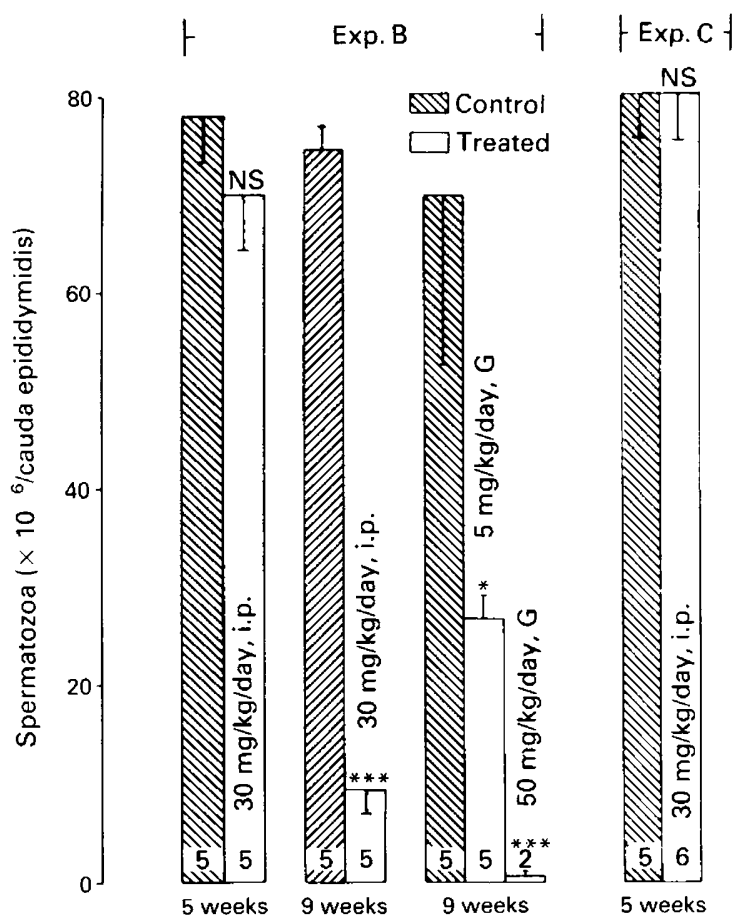

Fig. 6. Effect of procarbazine on epididymal sperm reserves. Values are mean \pm s.e.m. for the no. of rats indicated. ${ }^{*} P<0.05 ;{ }^{* *} P<0.001 ;$ i.p. $=$ intraperitoneal; $\mathrm{G}=$ gavage.

Table 2. Reproductive functions of male Sprague-Dawley rats receiving procarbazine for 5 and 9 weeks

\begin{tabular}{|c|c|c|c|c|}
\hline Experimental groups & & $\begin{array}{c}\text { Male } \\
\text { fertility index } \dagger \\
(\%)\end{array}$ & $\begin{array}{l}\text { Total } \% \text { of } \\
\text { pregnant females }\end{array}$ & $\begin{array}{l}\text { Mean } \pm \text { s.e.m. } \\
\text { no. of fetuses } \\
\text { per female }\end{array}$ \\
\hline \multicolumn{5}{|l|}{ Experiment $B$} \\
\hline $30 \mathrm{mg} / \mathrm{kg} /$ day for 5 weeks, i.p. & $\begin{array}{l}\text { Control } \\
\text { Treated }\end{array}$ & $\begin{array}{l}100(6 / 6) \\
100(6 / 6)\end{array}$ & $\begin{array}{l}92(11 / 12) \\
75(9 / 12)\end{array}$ & $\begin{array}{l}9.83 \pm 1 \cdot 3 \\
4.75 \pm 1 \cdot 2^{*}\end{array}$ \\
\hline $30 \mathrm{mg} / \mathrm{kg} /$ day for 9 weeks, i.p. & $\begin{array}{l}\text { Control } \\
\text { Treated }\end{array}$ & $\begin{array}{r}100(6 / 6) \\
86(6 / 7)\end{array}$ & $\begin{array}{l}92(11 / 12) \\
57(8 / 14)\end{array}$ & $\begin{array}{r}10 \cdot 58 \pm 1 \cdot 21 \\
3.43 \pm 1 \cdot 14^{*}\end{array}$ \\
\hline $5 \mathrm{mg} / \mathrm{kg} /$ day for 9 weeks, gavage & $\begin{array}{l}\text { Control } \\
\text { Treated }\end{array}$ & $\begin{array}{l}100(5 / 5) \\
100(5 / 5)\end{array}$ & $\begin{array}{r}100(10 / 10) \\
80(8 / 10)\end{array}$ & $\begin{array}{r}13.4 \pm 1.7 \\
9.8 \pm 2.0\end{array}$ \\
\hline $50 \mathrm{mg} / \mathrm{kg} /$ day for 9 weeks, gavage & Treated & $0(0 / 5)$ & $0(0 / 10)$ & 0 \\
\hline \multicolumn{5}{|l|}{ Experiment $C$} \\
\hline $30 \mathrm{mg} / \mathrm{kg} /$ day for 5 weeks, i.p. & $\begin{array}{l}\text { Control } \\
\text { Treated }\end{array}$ & $\begin{array}{r}100(6 / 6) \\
86(6 / 7)\end{array}$ & $\begin{array}{l}83(10 / 12) \\
57(8 / 14)\end{array}$ & $\begin{array}{l}9.42 \pm 1.43 \\
4.43 \pm 1.35^{*}\end{array}$ \\
\hline
\end{tabular}

$\dagger \%$ of males, with 1 or 2 pregnant females.

${ }^{*} P<0.00$ I, compared with control. 
rate was high and a marked decrease in the rate of weight gain in the animals was noted. In the other experimental groups the only indication of systemic toxicity was a decrease in body weight but this did not fall below $15 \%$ of the control values.

In man, procarbazine-containing regimens such as MOPP (methylchlorethamine, oncovin [Vincristine], procarbazine, prednisone) or MVPP (methylchlorethamine, vinblastine, procarbazine, prednisone), used in the treatments of Hodgkin's disease and testicular cancer, have been shown to induce testicular germinal aplasia associated with a marked decrease of testicular volume, severe oligospermia or azoospermia and sterility (Sherins \& DeVita, 1973; Sherins et al., 1978; Chapman et al., 1979, 1981; Andrieu et al., 1981; Whitehead et al., 1982).

The results of our histological study confirm previous observations showing that spermatogenic cells are also severely damaged in animals exposed to procarbazine treatment (rat: Hilscher \& Reichelt, 1968; Lee \& Dixon, 1972; Parvinen, 1979; Gould et al., 1983; Russell et al., 1983a, b; mouse: Meistrich et al., 1982; Sotomayor et al., 1982; Abraham \& Frantz, 1983; monkeys: Sieber et al., 1978). Degeneration of spermatogonia, primary spermatocytes and spermatids, retardation of spermatid maturation, and defective DNA, RNA and protein synthesis in spermatogenic cells are among the features reported after administration of this drug. It is noticeable from our results that the degree of alteration of spermatogenesis is proportional to the dose administered and to the duration of the treatment. Furthermore, this study also clearly demonstrates that treatment with procarbazine during the establishment of spermatogenesis (Exp. A: 10-45-day-old rats, $30 \mathrm{mg} / \mathrm{kg}$ / day $/ 5$ weeks, i.p.) leads to a much more rapid and extensive degeneration of the seminiferous epithelium than it does when the spermatogenic process is established (Exp. B: 45-day-old to adult rats, same dose regimen and duration). This may be due to the fact that the sensitivity of stem spermatogonia to antimitotic agents, in the immature testis is greater than the sensitivity of these cells in the post-pubertal testis. This has been shown by Erikson \& Blend (1976) after gamma irradiation of rat testes. This might also result from a general greater sensitivity of all germ cell categories during the first spermatogenic cycle, and highlight the particular risk in administering procarbazine containing polychemotherapies during puberty.

As in men in whom azoospermia is often found after polychemotherapies such as MOPP or MVPP (see references above), procarbazine induced a marked fall in sperm reserves after 9 weeks of treatment in the rat. The fact that no such change was seen after 5 weeks is compatible with our histological study showing that only a few seminiferous tubules were affected at this time. That sperm reserves were also significantly decreased after gavage with $5 \mathrm{mg}$ procarbazine $/ \mathrm{kg} / \mathrm{day}$ for 9 weeks most probably indicates that in this group some spermatogonia were affected by the anti-cancer drug.

Although germ cell degeneration was observed in almost all experimental groups after procarbazine treatment, Sertoli cells, often vacuolated, were always present in seminiferous tubules. This confirms previous observations in animals (Lee \& Dixon, 1972; Sieber et al., 1978; Gould et al., 1983) and in man (Sherins \& DeVita, 1973; Sherins et al., 1978; Chapman et al., 1979, 1981). However, when germ cell complement was most severely affected (Exps A and B after 9 weeks of treatment), a marked Sertoli cell dysfunction appeared as indicated by the decrease in ABP production and the increase of FSH concentrations, the former indirectly (and partly) reflecting inhibin production. That this results from a true decrease of Sertoli cell activity is indicated by the fact that ABP secretion fell by more than $58 \%$ and that $\mathrm{FSH}$ values rose by $30 \%$ in the rats receiving $30 \mathrm{mg} /$ $\mathrm{kg} /$ day for 9 weeks (Exp. B) whilst under similar conditions no change in Sertoli cell number was found by Gould et al. (1983). Since-germ cell degeneration always precedes Sertoli cell dysfunction it is likely, contrary to the suggestion of Parvinen (1979), that germ cells are the primary targets of procarbazine in the seminiferous tubules. Furthermore, the fact that the impairment of Sertoli cell characteristics always occurs in concert with the extension of germ cell damage to the last stages of spermatogenesis is consistent with our hypothesis of a possible interaction between late spermatids and Sertoli cells (Jégou et al., 1984, 1986). A selective rise in plasma FSH concentrations has also been shown in men with a total absence of germ cells and/or azoospermia after treatment with 
MOPP or MVPP (Sherins \& DeVita, 1973; Sherins et al., 1978; Chapman et al., 1981; Andrieu et al., 1981), which indicates that Sertoli cell dysfunction also occurs in men with the most severe damaged testicular function.

In contrast to the dramatic effects of procarbazine-containing chemotherapies on the seminiferous epithelium, several studies indicate that the susceptibility of Leydig cells to the cytotoxicity of anti-cancer treatments in man is moderate. This was evaluated by histological studies and by the measurement of circulating testosterone and LH concentrations (Van Thiel et al., 1972; Sherins \& DeVita, 1973; Asbjornsen et al., 1976; Chapman et al., 1979, 1981; Andrieu et al., 1981). However, a greater sensitivity of Leydig cells to MOPP treatment has been suggested in pubertal boys (Sherins et al., 1978). Our study reveals that Leydig cells are present in the interstitium of procarbazine-treated rats of all ages and that, independently of the age at which the treatments were begun, a moderate decrease in testosterone concentrations associated with no change in serum concentrations $\mathbf{L H}$ values is observed.

In men sterility occurs after anti-cancer chemotherapy treatments (see references above). Our results reveal that the fertility of rats treated with procarbazine is strikingly reduced in most experimental groups. A marked decrease in the number of fetuses per female also occurred for the animals treated for only 5 weeks (Exps B and C) despite the fact that, in these animals, no change in sperm reserves was seen. This is indicative of a direct effect of procarbazine on spermatozoa (DNA) and perhaps on the physiology of the epididymis.

This work was supported by a grant from the Association pour la Recherche sur le Cancer (No. 6339; A.R.C., 94801 Villejuif Cédex France) and partly by a grant from Institut National de la Santé et de la Recherche Médicale (No. 844019). J.F.V. de la C. is the recipient of a studentship from A.R.C. We thank Mr J. P. Dulor (ENSA, Montpellier) for the gift of the second antibody used in LH and FSH assays; Mrs A. M. Touzalin for skilled technical assistance; Mrs M. Mathelier for illustrations; Mrs M. M. Gaillard for typing; Mr Blanchet for the photographic work; and Ms J. Hall for revision of the English.

\section{References}

Abraham, S. \& Frantz, J. (1983) Induction of sisterchromatid exchanges by chemotherapeutic drugs in spermatogonia of mice: effects of procarbazine, adriamycine, cyclophosphamide and mitomycine $\mathrm{C}$. Mutat. Res. 108, 373-381.

Andrieu, J.M., Masson, D., Fiet, J., Gourmel, B., Czyglick, F. \& Bernard, J. (1981) La fertilité des jeunes hommes atteints de la maladie de Hodgkin avant et après chimiothérapie. La Nouvelle Presse Médicale 25, 2085-2088.

Asbjornsen, G., Molne, K., Kiepp, O. \& Aakvaag, A. (1976). Testicular function after combination chemotherapy for Hodgkin's disease. Scand. J. Haemat., 16, 66-69.

Chapman, R.M., Sutcliffe, S.B., Rees, L.H., Edwards, C.R.W. \& Malpas, J.C. (1979) Cyclical combination chemotherapy and gonadal function. Lancet 1, 285-289.

Chapman, R.M., Sutcliffe, S.B. \& Malpas, J.C. (1981) Male gonadal dysfunction in Hodgkin's disease. A prospective study. J. am. med. Assoc. 245, 1323-1328.

de Kretser, D.M., Sharpe, R.M. and Swanston, I.A. (1979) Alterations in steroidogenesis and human chorionic gonadotropin binding in the cryptorchid rat testis. Endocrinology 105, 135-138.
DeVita, V.T. (1981) The consequences of the chemotherapy of Hodgkin's disease: the 10th David A. Karnofsky Memorial Lecture. Cancer 47, 1-13.

Erickson, B.H. \& Blend, J. (1976) Response of the Sertoli cell and stem germ cell to ${ }^{60} \mathrm{Co} \gamma$-radiation (dose and dose rate) in testes of immature rats. Biol. Reprod. 14, $641-650$.

Garnier, D.H., Cotta, Y. \& Terqui, M. (1978) Androgen radioimmunoassay in the ram: results of direct plasma testosterone and dehydroepiandrosterone measurement and physiological evaluation. Annls Biol. Anim. Biochim. Biophys. 18, 265-281.

Gould, S.F., Powell, D., Nett, T. \& Glode, L.M. (1983) A rat model for chemotherapy-induced male infertility. Archs Androl. 11, 141-150.

Hilscher, W. \& Reichelt, P. (1968) Effect of cyclophosphamide and procarbazine on the seminiferous epithelium in the rat. Beitr. Path. Anat. 137, 452-478.

Jégou, B., Laws, A.O. \& de Kretser, D.M. (1984) Changes in testicular function induced by short-term exposure of rat to heat: further evidence for interaction of germ cells, Sertoli cells and Leydig cells. Int . J. Androl. 7, 244-257.

Jégou, B., Le Magueresse, B., Pinon-Lataillade G., Velez de la Calle, J.F., Garnier, D.H., Maas, J. \& Boisseau, C. (1986) In vitro and in vivo studies of germ cell 
influence upon Sertoli cell function. In Molecular and Cellular Endocrinology of the Testis, pp. 63-68. Eds M. Stefanini, M. Conti, R. Geremia \& E. Ziparo. Elsevier Science Publishers B.V. (Biomedical Division), Amsterdam.

Lee, I.P. \& Dixon, R.L. (1972) Effects of procarbazine on spermatogenesis determined by velocity sedimentation cell separation technique and serial mating. $J$. Pharmacol exp. Ther. 181, 219-226.

Meistrich, M., Finch, M., Dacunha, M., Hacker, U. \& Au, W. (1982) Damaging effects of fourteen chemotherapeutic drugs on mouse testis cells. Cancer Res. 42, 122-131.

Parvinen, L. (1979) Early effects of procarbazine (Nisopropyl 2-methylhydrazine-p-toluamide hydrochloride) on rat spermatogenesis. Exp. molec. Path. 30, 1-11.

Ritzen, E.M., French, F.S., Weddington, S.C., Nayfeh, S.N. \& Hansson, V. (1974) Steroid binding in polyacrylamide gels. J. biol. Chem. 249, 6597-6604.

Robb, G.W., Amann, R.P. and Killiam, G.J. (1978) Daily sperm production and epididymal sperm reserves of pubertal and adult rats. J. Reprod. Fert. 54, 103-107.

Russell, L.D., Lee, I.P., Ettlin, R. \& Malone, J.P. (1983a) Morphological pattern of response after administration of procarbazine: alteration of specific cell associations during the cycle of the seminiferous epithelium of the rat. Tissue and Cell 15, 391-404.

Russell, L.D., Lee, I.P., Ettlin, R. \& Peterson, R.N. (1983b) Development of the acrosome and alignment, elongation and entrenchment of spermatids in procarbazine-treated rats. Tissue and Cell 15, 615-626.
Sehilsky, R.L., Lewis, B.J., Sherins, R.J. and Young, R.C. (1980) Gonadal dysfunction in patients receiving chemotherapy for cancer. Annals intern. Med. 93, $109-114$.

Shalet, S.M. (1983) Disorders of the endocrine system due to radiation and cytotoxic chemotherapy. Clin. Endocr $18,637-659$.

Sherins, R.J. \& DeVita, V.T., Jr (1973) Effect of drug treatment for lymphoma on male reproductive capacity: studies of men in remission after therapy. Annls intern. Med. 79, 216-220.

Sherins, R.J., Olweny, C.L.M. \& Ziegler, J.L. (1978) Gynecomastia and gonadal dysfunction in adolescent boys treated with combination chemotherapy for Hodgkin's disease. New Engl. J. Med. 299, 12-16.

Sieber, S.M., Correa, P., Dalgard, D.W. \& Adamson, R.H. (1978) Carcinogenic and other adverse effects of procarbazine in non-human primates. Cancer Res. 38, $2125-2134$.

Sotomayor, R., Chauhan, P. \& Ehling, U. (1982) Induction of unscheduled DNA synthesis in the germ cells of male mice after treatment with hydrazine or procarbazine. Toxicology 25, 201-211.

Van Thiel, D.H., Sherins, R.J., Myers, G.H. \& DeVita, V.T. (1972) Evidence for a specific seminiferous tubular factor affecting FSH secretion in man. J. clin. Invest. 51, 1009-1019.

Whitehead, E., Shalet, S.M., Blackledge, G., Todd, I., Crowther, D. \& Beardwell, C.G. (1982) The effect of Hodgkin's disease and combination chemotherapy on gonadal function in the adult male. Cancer 49, $418-422$.

Received 3 November 1987 